\title{
Strongly increasing heat extremes in the Middle East and North Africa (MENA) in the 21st century
}

\author{
J. Lelieveld ${ }^{1,2} \cdot$ Y. Proestos $^{2} \cdot$ P. Hadjinicolaou ${ }^{2}$ • \\ M. Tanarhte $^{1} \cdot$ E. Tyrlis ${ }^{2} \cdot$ G. Zittis $^{2}$
}

Received: 2 September 2015 / Accepted: 25 March 2016 /Published online: 23 April 2016

(C) The Author(s) 2016. This article is published with open access at Springerlink.com

\begin{abstract}
The ensemble results of CMIP5 climate models that applied the RCP4.5 and RCP8.5 scenarios have been used to investigate climate change and temperature extremes in the Middle East and North Africa (MENA). Uncertainty evaluation of climate projections indicates good model agreement for temperature but much less for precipitation. Results imply that climate warming in the MENA is strongest in summer while elsewhere it is typically stronger in winter. The summertime warming extends the thermal low at the surface from South Asia across the Middle East over North Africa, as the hot desert climate intensifies and becomes more extreme. Observations and model calculations of the recent past consistently show increasing heat extremes, which are projected to accelerate in future. The number of warm days and nights may increase sharply. On average in the MENA, the maximum temperature during the hottest days in the recent past was about $43{ }^{\circ} \mathrm{C}$, which could increase to about $46^{\circ} \mathrm{C}$ by the middle of the century and reach almost $50{ }^{\circ} \mathrm{C}$ by the end of the century, the latter according to the RCP8.5 (business-as-usual) scenario. This will have important consequences for human health and society.
\end{abstract}

\section{Introduction}

Even if climate change in the 21 st century will be limited to a global mean temperature increase of $2{ }^{\circ} \mathrm{C}$ relative to pre-industrial times, warming over land is typically stronger than over the oceans and extreme temperatures in many regions can increase well beyond $2{ }^{\circ} \mathrm{C}$ (Seneviratne et al. 2016). The Middle East and North Africa (MENA) are expected to be

Electronic supplementary material The online version of this article (doi:10.1007/s10584-016-1665-6) contains supplementary material, which is available to authorized users.

J. Lelieveld

jos.lelieveld@mpic.de

1 Max Planck Institute for Chemistry, 55020 Mainz, Germany

2 The Cyprus Institute, P.O. Box 27456, 1645 Nicosia, Cyprus 
strongly affected by climate warming, enhancing the already hot and dry environmental conditions (Sanchez et al. 2004; Fang et al. 2008; Giorgi and Lionello 2008; Önol and Semazzi 2009; Lelieveld et al. 2012; Almazroui 2013: Önol et al. 2014; Basha et al. 2015; Ozturk et al. 2015). Assessments of past climate trends in the MENA often suffered from restricted availability of meteorological data sets, and hence are associated with low confidence (IPCC 2013). Several international workshops have been organized to help improve data access, ensure data quality and analyze climate indices (Zhang et al. 2005; Donat et al. 2014).

Based on the available data significant upward temperature trends since the 1970s have been derived for parts of the MENA and Mediterranean Europe (AlSarmi and Washington 2011; Almazroui et al. 2012; Tanarhte et al. 2012; Zarenistanak et al. 2014), accompanied by an increasing number of warm days and high temperature extremes (Kuglitsch et al. 2010; Marofi et al. 2010; Efthymiadis et al. 2011; Donat et al. 2014; Simolo et al. 2014; Tanarhte et al. 2015). While rainfall trends in Mediterranean Europe are significant and predominantly negative, in the MENA they are generally not significant, partly related to the difficulty of establishing representative precipitation measurement networks in this arid region (Xoplaki et al. 2004; Hoerling et al. 2012; Tanarhte et al. 2012; Norrant-Romand and Douguedroit 2014; Ziv et al. 2014).

Analysis of long-term temperature data suggests that since the 1970s the frequency of heat extremes has increased in the MENA (Tanarhte et al. 2015). Based on health statistics and meteorological data Lubczyńska et al. (2015) identified a clear relationship between high temperatures and cardiovascular mortality by cerebrovascular disease, ischemic and other heart diseases, consistent with similar investigations in other regions (Basu and Samet 2002; Gosling et al. 2009). Heat extremes are recognized as the major weather-related cause of premature mortality (McMichael et al. 2006; Kovats and Hajat 2008; Gosling et al. 2009; Peterson et al. 2013), hence their increase in the MENA is of great concern (Lelieveld et al. 2014; Zittis et al. 2015). Heat stress can also cause substantial loss of labor productivity (Dunne et al. 2013; Zander et al. 2015). Further, it is argued that climate change induced weather extremes can impact human security and migration (Barnett and Adger 2007; Piguet et al. 2010; IPCC 2014). Thus heat stress has direct health consequences, while social, economic and political contexts are also important. Both perspectives are relevant for the MENA.

One of the difficulties in the assessment of temperature related climate impacts is the definition of hot weather extremes. Therefore, it is recommended to apply a range of climate indices such as heat wave frequency and warm spell duration (WMO 2009). Zittis et al. (2015) showed that the probability density distributions of daytime maximum temperatures in the warm temperate climate regime north of the Mediterranean are typically wider than in the arid areas to the south. In the latter case the extreme values are comparatively close to the median and mean of the maximum temperature distribution, so that even a moderate rate of warming can lead to the exceeding of heat wave thresholds.

Motivated by the demand for information about regional climate trends, we present projected changes in summertime hot weather conditions in the MENA during the 21 st century based on the ensemble output of climate models that participated in the Coupled Model Intercomparison Project Phase 5, CMIP5 (Taylor et al. 2012; Sillmann et al. 2013a, 2013b). We evaluate CMIP5 model uncertainties for the MENA by comparing with observations, and also based on the robustness metric (Knutti and Sedlacek 2012), and show that the models consistently project strong temperature changes whereas precipitation projections are much less consistent. This rationalizes the present focus on temperature extremes, whereas for 
precipitation higher resolution regional downscaling will be more appropriate. For the latter we refer to the Coordinated Regional Climate Downscaling Experiment framework for the region, MENA-CORDEX (Giorgi et al. 2009; Zittis et al. 2014a; Almazroui 2015).

\section{MENA description}

The definition of the MENA, applied here, encompasses the larger region between Morocco and Iran, including all Middle Eastern and Maghreb countries, sometimes indicated as Greater Middle East (http://en.wikipedia.org/wiki/MENA). The 29 countries included are Algeria, Armenia, Azerbaijan, Bahrain, Cyprus, Djibouti, Egypt, Georgia, Iran, Iraq, Israel, Jordan, Kuwait, Lebanon, Libya, Mauretania, Morocco, Oman, Palestine, Qatar, Saudi Arabia, Somalia, Sudan, Syria, Tunisia, Turkey, United Arab Emirates, Western Sahara and Yemen, with a current population of about 550 million people. While focusing on these countries, we will likewise present climate model output for the MENA-CORDEX area, which includes part of Central Africa, also addressed within Africa-CORDEX (http://www.cordex.org).

Notice that the domain of Africa-CORDEX does not fully cover the Anatolian Peninsula and the Middle East. Because the climate of Central Africa deviates strongly from that in the MENA, being humid - monsoonal rather than hot and arid, respectively, these results are not analyzed in the present context. To evaluate the CMIP5 model data for the MENA we define four subregions that are climatically coherent (Fig. 1, top panel), based on the Köppen-Geiger climate type classification (Kottek et al. 2006). Geographical coordinates of the subregions are the following. A: $9.25 \mathrm{~W}-12.0 \mathrm{E}, 30.0-39.0 \mathrm{~N} ; \mathrm{B}: 12.0-34.0 \mathrm{E}, 25.0-33.0 \mathrm{~N} ; \mathrm{C}: 25.5-46.5 \mathrm{E}$, 33.0-41.0 N; D: 34.0-60.0E, 18.0-33.0 N. In Section 4 we compare the CMIP5 model output with temperature observations in these subregions. The Supplementary Information includes a Köppen-Geiger analysis of the CMIP5 calculations for recent, mid- and end-century conditions in the MENA, showing that the main climate types are not expected to change much in the 21st century, i.e., remaining hot and arid (Figure S1).

\section{Data and methods}

From the CMIP5 output we applied results from an ensemble of 26 models that have been interpolated to a common spatial resolution of 2.5 degrees, about $280 \mathrm{~km}$ at the equator (Table S1) (Taylor et al. 2012; Sillmann et al. 2013a, 2013b). Here we use CMIP5 model results for two Representative Concentration Pathways (RCPs), RCP4.5 and RCP8.5, adopted by the IPCC for its fifth Assessment Report (IPCC 2013). Greenhouse gas emissions according to RCP4.5 are assumed to peak around 2040 and then decline, while in RCP8.5 emissions continue to rise throughout the 21 st century and hence represent a business-as-usual scenario. Following IPCC (2013) we compare the mid-century period 2046-2065 and the end-century period 2081-2100 with the recent period 1986-2005, the latter used as reference.

We evaluate the CMIP5 model results for the reference period, based on observations compiled in the gridded datasets of the Climate Research Unit (CRU, version 3.22) (Mitchell and Jones 2005) and the University of Delaware (UDEL, version 3.01) (Willmott and Matsuura 1995), also used and inter-compared by Tanarhte et al. (2012). To characterize changes in temperature conditions and hot weather extremes, we follow the procedure of Sillmann et al. (2013a, 2013b) by applying the climate indices defined by the Expert Team on 

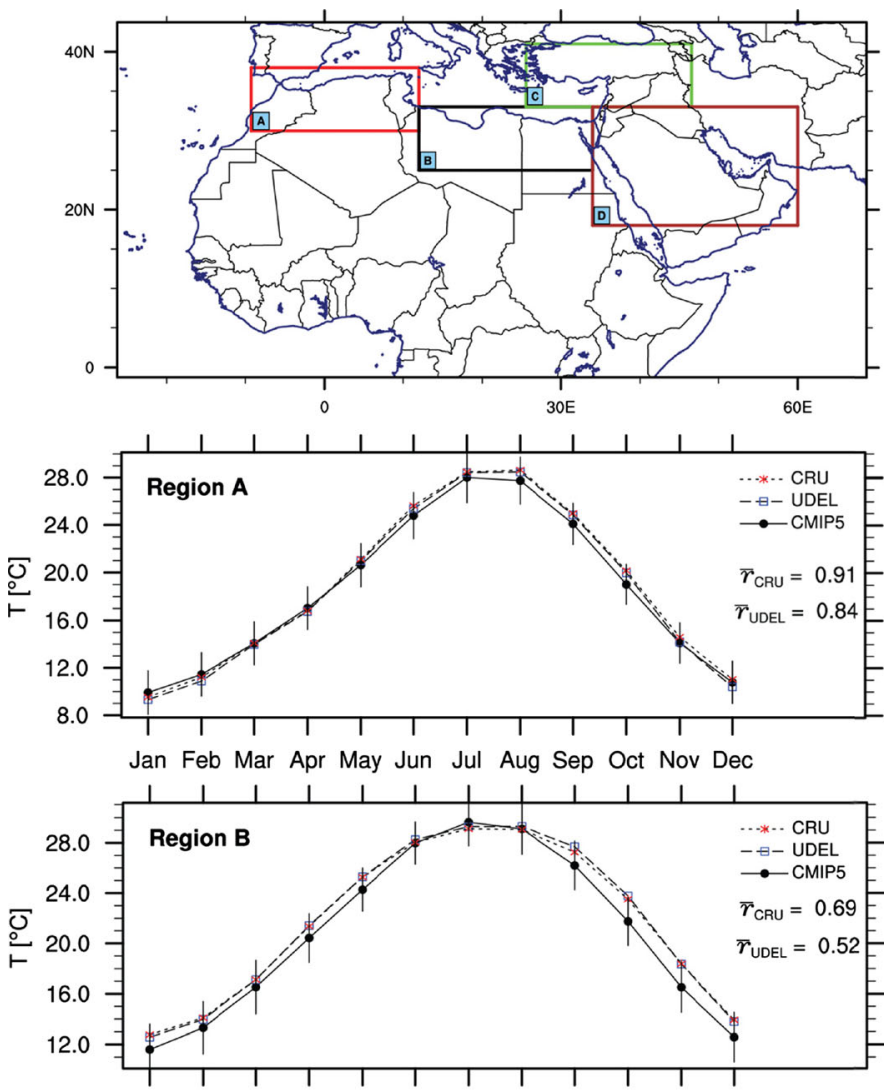

Jan Feb Mar Apr May Jun Jul Aug Sep Oct Nov Dec
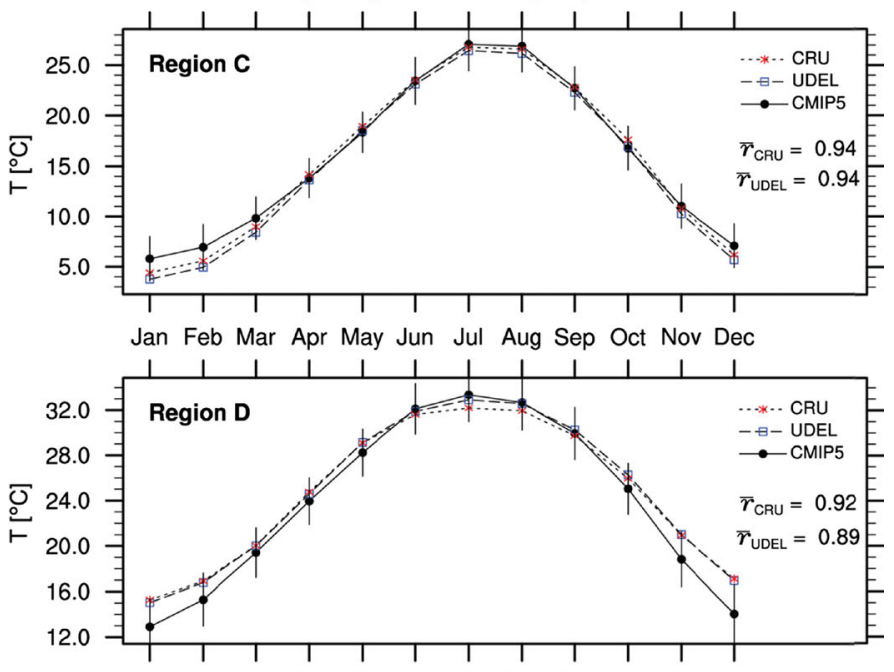

Jan Feb Mar Apr May Jun Jul Aug Sep Oct Nov Dec

Fig. 1 CMIP5 multi-model mean monthly temperature for four MENA subregions compared to observations during the reference period 1986-2005 collected in the CRU and UDEL datasets. Model standard deviations and mean correlation coefficients between model and measurement data are indicated 
Climate Change Detection and Indices (ETCCDI) of the World Meteorological Organization (WMO) (Klein Tank et al. 2009; Zhang et al. 2011) to the MENA, i.e., over the area of the 29 countries listed in Section 2, as well as the subregions defined in Fig. 1. The indices are calculated for the RCP4.5 and 8.5 scenarios, and are available from the ETCCDI archive at http://www.cccma.ec.gc.ca/data/climdex/index.shtml. The CMIP5 model output is compared with historical observations in the period 1950-2010 from the HadEX2 data set of the UK Met Office Hadley Centre. Monthly and annual indices, based on selected high-quality station observations in 14 MENA countries, have been obtained from http://www.climdex.org/index.html (Donat et al. 2013, 2014).

To test the level of consistency of the climate model projections we performed robustness calculations as proposed by Knutti and Sedlacek (2012); see also Proestos et al. (2015). The projection maps of near-surface (2-m) temperature and precipitation for the RCP4.5 and RCP8.5 scenarios are overlaid by stippling and cross-hatching to indicate robustness $R$, based on the signal-variability ratio and the probability skill score, adopted from weather forecasting applications (Weigel et al. 2007). The signal-variability ratio is calculated from the CMIP5 model spread and the projected change in a particular parameter such as temperature or precipitation. $R=1-\mathrm{X}_{1} / \mathrm{X}_{2}$, in which $\mathrm{X}_{1}$ is the integral of the squared area between cumulative density functions of individual and multi-model mean projections, and $\mathrm{X}_{2}$ the integral of the squared area between cumulative density functions of the multi-model projection and the historical reference period. A value of $R=1$ indicates absolute model agreement.

\section{CMIP5 model results}

Figure 1 shows a comparison between observations and CMIP5 model output of the ensemble mean monthly temperature, including the standard deviation of all model results. The spatial correlation between CMIP5 and observations is high, especially with the CRU dataset. In all four regions the agreement between model and observations is very good for the summer months (June-August), being the focus of the present work. For the winter, typically October to February, differences can be up to several degrees. In regions $\mathrm{B}$ and D the CMIP5 ensemble mean appears to be cold-biased and in region $\mathrm{C}$ warmbiased during these months.

Figure 2 presents the projected changes in near-surface temperature, including $R$, for the mid- and end-century periods and the RCP 4.5 and 8.5 scenarios. The interested reader is referred to Figure $\mathrm{S} 2$ for the accompanying results for precipitation. We present projections for winter, i.e., the wet season (December, January, February - DJF) and summer, i.e., the dry season (June, July, August - JJA). While our focus is on the summer, we also present results for the winter to emphasize the seasonal differences in warming trends. This illustrates that the rate of warming is much higher in summer. Please notice the temperature scale differences between the two scenarios. Figure 2 shows that the level of robustness is high, especially for the summer warming, and is highest for the end-of-century projections, in particular for the RCP8.5 scenario, indicating overall agreement among the models. The robustness for precipitation projections, on the other hand, is generally much lower (Figure S2).

On average the CMIP5 models project a drying tendency in the Mediterranean area, which is partly robust in the RCP8.5 projections (Figure S2) and in accord with previous analyses (IPCC 2013). Conversely, northeastern Africa, including part of the Sahara and the Sahel as 

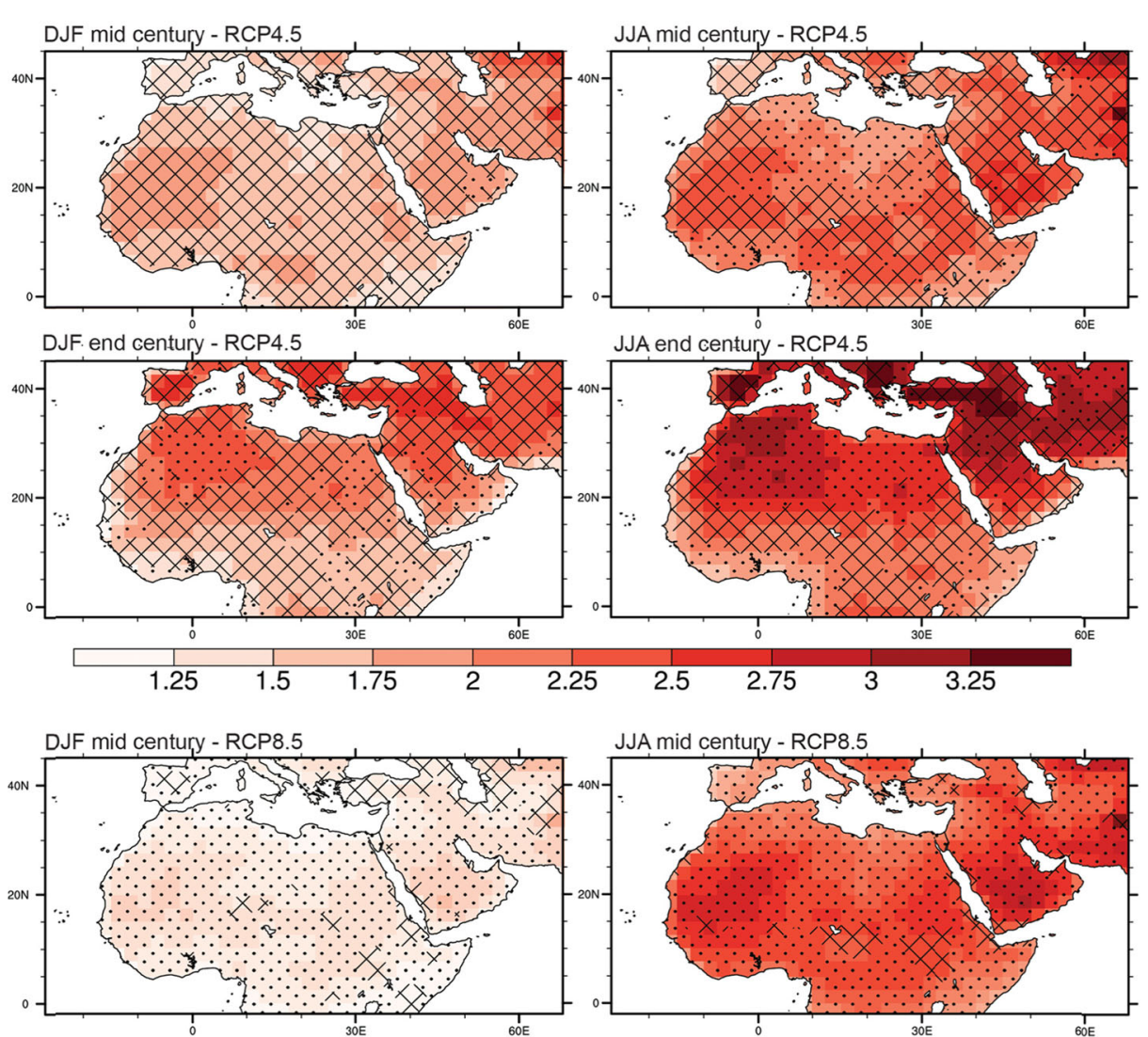

JJA mid century - RCP8.5

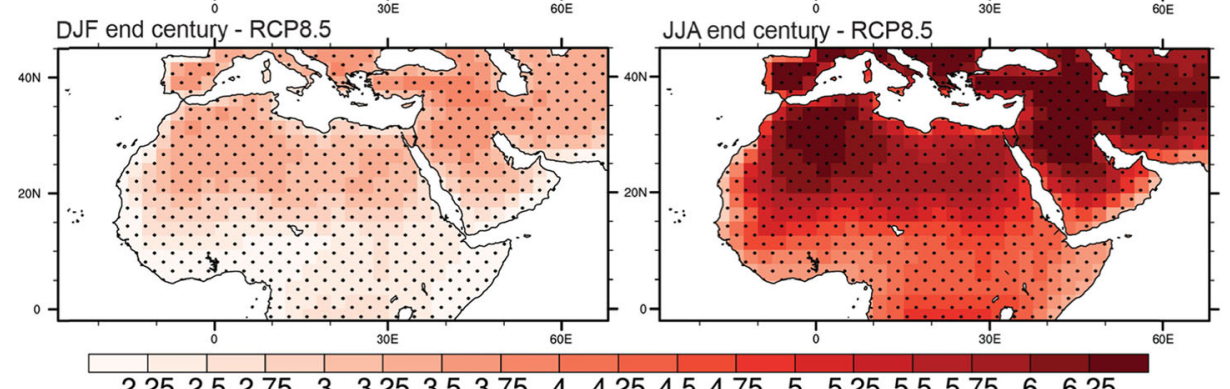

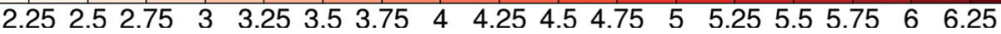

Fig. 2 Multi-model mean and robustness (dots $R \geq 0.85$, and cross-hatching $0.5 \leq R<0.85$ ) for the change in near-surface temperature in degrees K during DJF (left) and JJA (right) for 2046-2065 (mid-century) and 20812100 (end-century) relative to 1986-2005, according to the RCP4.5 and RCP8.5 scenarios

well as the Arabian region, are subject to moistening, which is less robust though consistent with observations in the recent past (Tanarhte et al. 2012). The drying is most significant in the northern Mediterranean region with a warm temperate climate, associated with rainfall in winter and spring. In this area declining precipitation in the 21 st century amplifies warming through the depletion of soil moisture, which suppresses surface cooling by limiting evapotranspiration (Seneviratne et al. 2010; Hirschi et al. 2011). This positive soil moisture feedback on temperature, however, is absent in the arid MENA where the surface energy budget is governed by radiative rather than evaporative cooling (Zittis et al. 2014b). 


\section{Expanding thermal low in summer}

Figure 2 demonstrates that climate warming in the MENA is particularly strong in summer, whereas during winter the projected rate of warming does not seem exceptional. In summer, subsidence leads to cloud-free and hot weather conditions over a region that extends from northwestern Africa to the Middle East (Tyrlis et al. 2013). At the surface a strong west-east pressure gradient between the Azores high and the Persian trough gives rise to northerly winds that ventilate North Africa by advection of relatively cooler air from Europe (Ziv et al. 2004), illustrated by the arrows in the upper panel of Fig. 3. The Persian trough is a thermal low that can be understood as an extension of the South Asian monsoon trough (Bitan and Saaroni 1992; Alpert et al. 2004). Remote diabatic heating by the South Asian monsoon induces a westward Rossby wave pattern, which enhances subsidence over the MENA with a maximum near the eastern Mediterranean (Rodwell and Hoskins 1996; Tyrlis et al. 2013).

According to IPCC (2013) global mean warming is projected to reach about $2{ }^{\circ} \mathrm{C}$ around 2050, i.e., slightly less for the RCP4.5 and slightly higher than $2{ }^{\circ} \mathrm{C}$ for the RCP8.5 scenario. Figure 2 indicates that the $2{ }^{\circ} \mathrm{C}$ approximately coincides with the mid-century warming in the MENA during winter in the RCP4.5 scenario, albeit that IPCC (2013) relates to pre-industrial times while Fig. 2 refers to the 1986-2005 period. It also illustrates that the magnitude of warming during summer is about twice that during the winter. According to the RCP8.5 scenario, by the end of the century large parts of the MENA in summer are projected to experience a temperature increase in excess of $6^{\circ} \mathrm{C}$ relative to 1986-2005. Figure 2 moreover shows that climate warming in the MENA is stronger than in tropical Africa, where hydrological feedbacks through cloud formation limit the increase of temperature at the surface.

In many areas climate warming is associated with an increase in evaporation and latent heat flux that cool the surface, including the Mediterranean Sea. However, in arid regions this is different, while the capacity to store heat within the soil is small, and surface heat imbalances are primarily compensated by longwave radiation flux adjustment (Vizy et al. 2013). This corresponds to the energy-controlled (vs. evapotranspiration-controlled) regime defined by Koster et al. (2009). Furthermore, increasing greenhouse gases, including water vapor, enhance the downward component of the longwave flux, which is particularly relevant under clear skies. Vizy et al. (2013) analyzed CMIP5 model results, concluding that the coupling of longwave radiation between the desert soil surface and lower atmosphere amplifies warming and intensifies the summertime heat low over the Sahara. Evan et al. (2015) also diagnosed CMIP5 model output and corroborate the deepening of the North African heat low, which they furthermore connect to an intensification of the West African monsoon and increasing precipitation in the Sahel (Figure S2).

The CMIP5 multi-model projections of mean sea level pressure (SLP) in the winter season suggest a significant increase over the Mediterranean and southern Europe, with a maximum around $40^{\circ} \mathrm{N}$, while SLPs south of $25^{\circ} \mathrm{N}$ decrease, with negligible changes in-between over North Africa. This can be understood as an impact of the widening tropical belt (Seidel et al. 2008). During summer, on the other hand, the CMIP5 projections show a reduction of mean SLP over the entire area between the tropics and mid-latitudes (Fig. 3). This coincides with decreasing geopotential height (GPH) at $1000 \mathrm{hPa}$ (Figure S3). This GPH decrease only occurs near the surface, while at higher altitudes, e.g., at 500 and $200 \mathrm{hPa}$, increases of GPH are projected, both in winter and summer. The CMIP5 model projections for the summer furthermore suggest that over northeastern Africa and the Middle East northerly winds weaken, so that ventilation from the north is reduced (Fig. 3). In spite of the low level heating in summer, indicated by the decrease in SLP, subsidence remains strong, which suppresses cloud formation. 


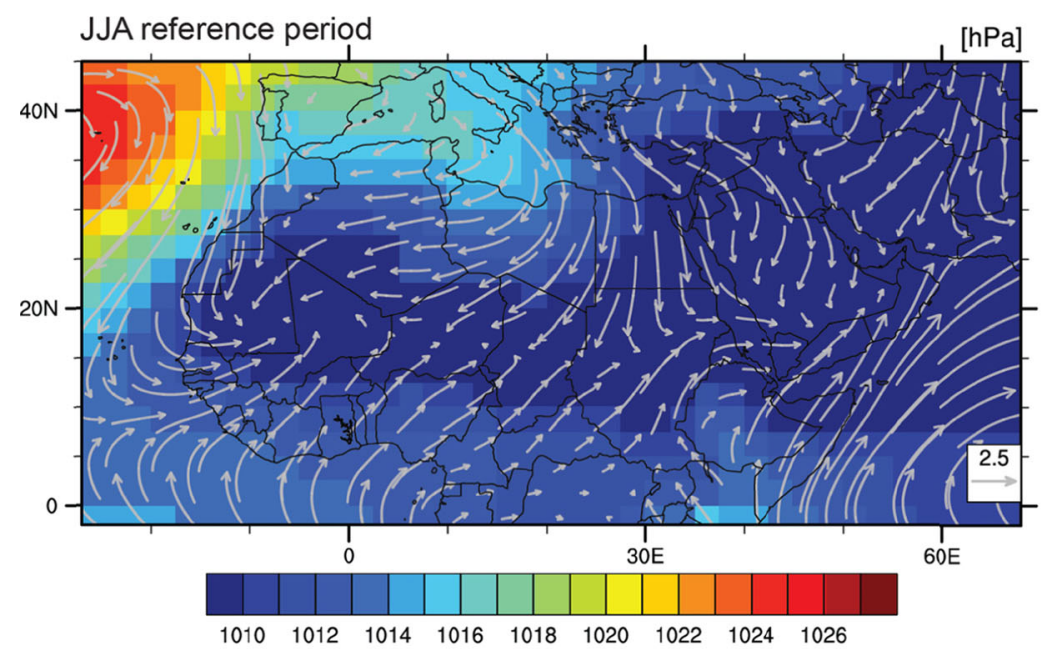

JJA mid century - RCP4.5
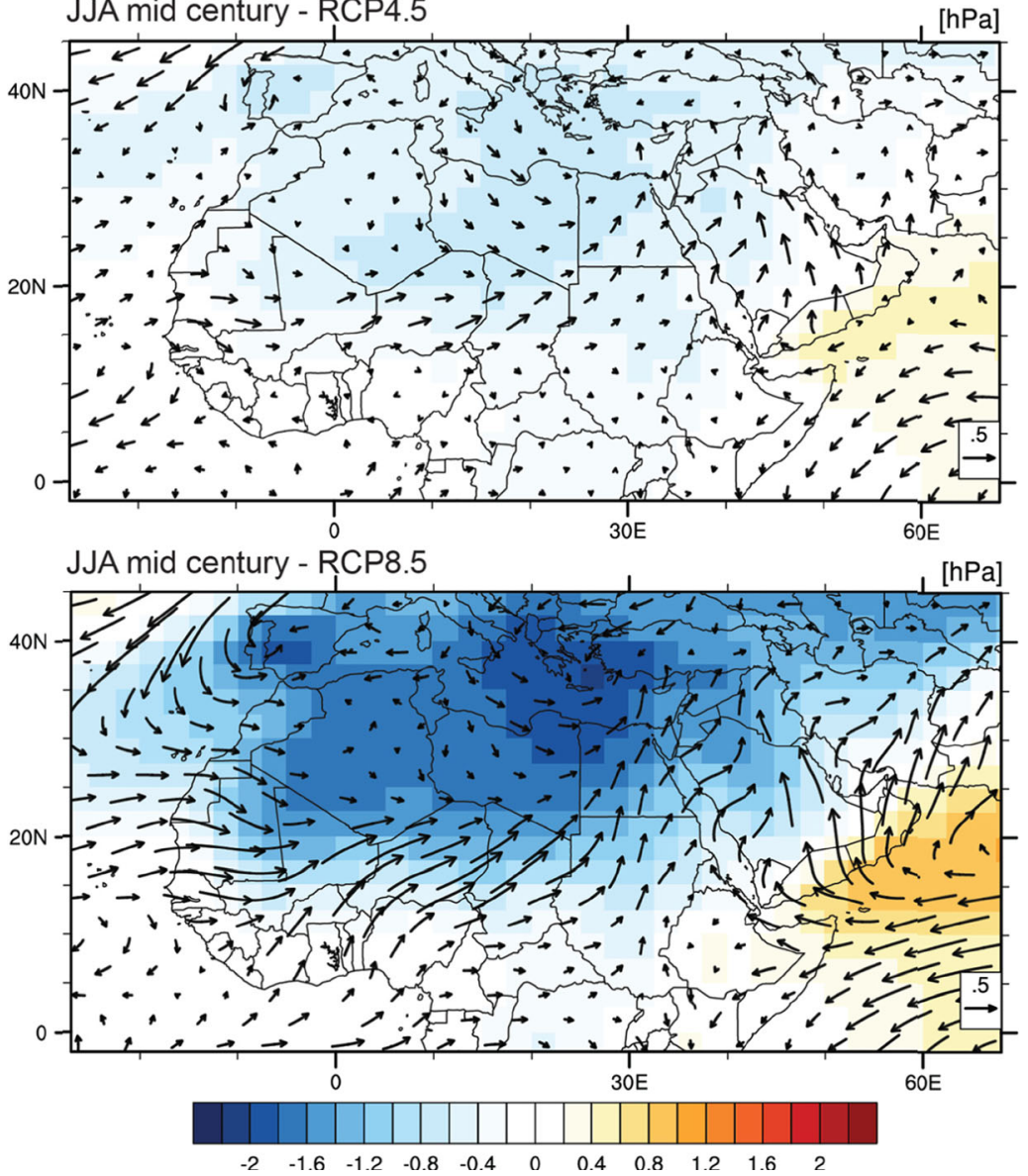

Fig. 3 Multi-model mean sea level pressure (SLP in $\mathrm{hPa}$ ) and wind vectors ( $\mathrm{m} / \mathrm{s})$ for the reference period $1986-$ 2005 (top), and projected mean anomalies in the 2046-2065 period for the RCP4.5 (middle) and RCP8.5 (bottom) scenarios 
The GPH increase throughout most of the troposphere in summer is consistent with the projected poleward shift of the subtropical jet stream (Yin 2005; Bengtsson et al. 2006). This is a consequence of the weakening meridional temperature gradient and the westward expansion of the upper level ridge induced by the monsoon. The latter also causes and increase of tropopause fold activity during summer (Tyrlis et al. 2014). The shift of the jet stream contributes to decreasing precipitation in the Mediterranean region. These projected changes are a continuation and therefore consistent with an observed and CMIP5 model simulated negative SLP trend over the period 1951-2011 (Gillett et al. 2013). Thus the SLP decrease in the MENA during summer can be interpreted as an extension of the Persian trough across the eastern Mediterranean and the Middle East, in combination with the intensifying thermal low over North Africa, and is associated with excessive heating.

\section{Changing temperature extremes}

The temperature-based indices are calculated for the selected 20-year reference and future periods, defined by IPCC (2013), as well the entire CMIP5 simulated time period 1950-2010. The results are presented in Table 1 and Figs. 4 and 5. Figure 4 shows results for the RCP8.5 scenario while the accompanying results for the RCP4.5 scenario are shown in Figure S4. A major difference between the two is that in RCP4.5 greenhouse gas emissions are curbed by mid-century, whereas they are not in RCP8.5. The indices presented here are a subset of those used by Sillmann et al. (2013a, 2013b), as we have disregarded the ones for summer days, tropical nights and cold spell duration, because the MENA temperatures already exceed the relevant thresholds in the reference period. The percentile indices are the rates (in percent) at which thresholds are exceeded, based on the annual cycle of the percentiles calculated for 5-day windows in the reference period of 1986-2005.

Table 1 Temperature extreme indices recommended by the ETCCDI calculated from CMIP5 model results according to the RCP4.5 and RCP8.5 scenarios, and from HadEX2 observations, averaged over the MENA countries. The \pm ranges indicate $1 \sigma$ standard deviations of the mean

\begin{tabular}{|c|c|c|c|c|c|c|}
\hline \multirow[b]{2}{*}{$\begin{array}{l}\text { ETCCDI } \\
\text { index }\end{array}$} & \multicolumn{2}{|c|}{$\begin{array}{l}\text { Reference period } \\
1986-2005\end{array}$} & \multicolumn{2}{|l|}{$\begin{array}{l}\text { Mid-century } \\
\text { 2046-2065 }\end{array}$} & \multicolumn{2}{|l|}{$\begin{array}{l}\text { End-century } \\
2081-2100\end{array}$} \\
\hline & HadEX2 & CMIP5 & $\begin{array}{l}\text { CMIP5 } \\
\text { RCP4.5 }\end{array}$ & $\begin{array}{l}\text { CMIP5 } \\
\text { RCP8.5 }\end{array}$ & $\begin{array}{l}\text { CMIP5 } \\
\text { RCP4.5 }\end{array}$ & $\begin{array}{l}\text { CMPI5 } \\
\text { RCP8.5 }\end{array}$ \\
\hline TN10p (\%) & $6.70 \pm 2.13$ & $7.16 \pm 0.57$ & $1.83 \pm 0.62$ & $1.03 \pm 0.51$ & $1.37 \pm 0.56$ & $0.28 \pm 0.20$ \\
\hline TN90p (\%) & $16.45 \pm 1.53$ & $15.52 \pm 1.30$ & $41.44 \pm 8.22$ & $53.61 \pm 8.77$ & $47.51 \pm 9.11$ & $75.67 \pm 7.52$ \\
\hline TX10p (\%) & $7.91 \pm 0.96$ & $8.07 \pm 0.44$ & $2.94 \pm 0.56$ & $2.09 \pm 0.55$ & $2.30 \pm 0.51$ & $0.85 \pm 0.40$ \\
\hline TX90p (\%) & $13.81 \pm 1.38$ & $14.91 \pm 1.27$ & $37.30 \pm 8.24$ & $46.49 \pm 9.08$ & $42.93 \pm 9.25$ & $66.79 \pm 8.73$ \\
\hline $\mathrm{TNn}\left({ }^{\circ} \mathrm{C}\right)$ & $-1.18 \pm 6.66$ & $-0.50 \pm 7.25$ & $1.24 \pm 7.10$ & $2.13 \pm 7.13$ & $1.74 \pm 7.10$ & $4.25 \pm 7.08$ \\
\hline $\mathrm{TNx}\left({ }^{\circ} \mathrm{C}\right)$ & $27.09 \pm 2.97$ & $28.38 \pm 3.01$ & $30.58 \pm 2.99$ & $31.64 \pm 3.02$ & $31.07 \pm 2.98$ & $34.32 \pm 3.08$ \\
\hline $\mathrm{TXn}\left({ }^{\circ} \mathrm{C}\right)$ & $9.92 \pm 8.13$ & $9.90 \pm 8.02$ & $11.60 \pm 7.90$ & $12.30 \pm 7.92$ & $12.04 \pm 7.90$ & $14.29 \pm 7.85$ \\
\hline $\mathrm{TXx}\left({ }^{\circ} \mathrm{C}\right)$ & $41.99 \pm 3.20$ & $43.44 \pm 3.79$ & $45.67 \pm 3.77$ & $46.67 \pm 3.83$ & $46.23 \pm 3.77$ & $49.23 \pm 3.90$ \\
\hline WSDI (days) & $10.64 \pm 4.34$ & $16.24 \pm 3.61$ & $83.17 \pm 31.41$ & $118.16 \pm 38.55$ & $104.39 \pm 37.72$ & $204.32 \pm 41.59$ \\
\hline
\end{tabular}



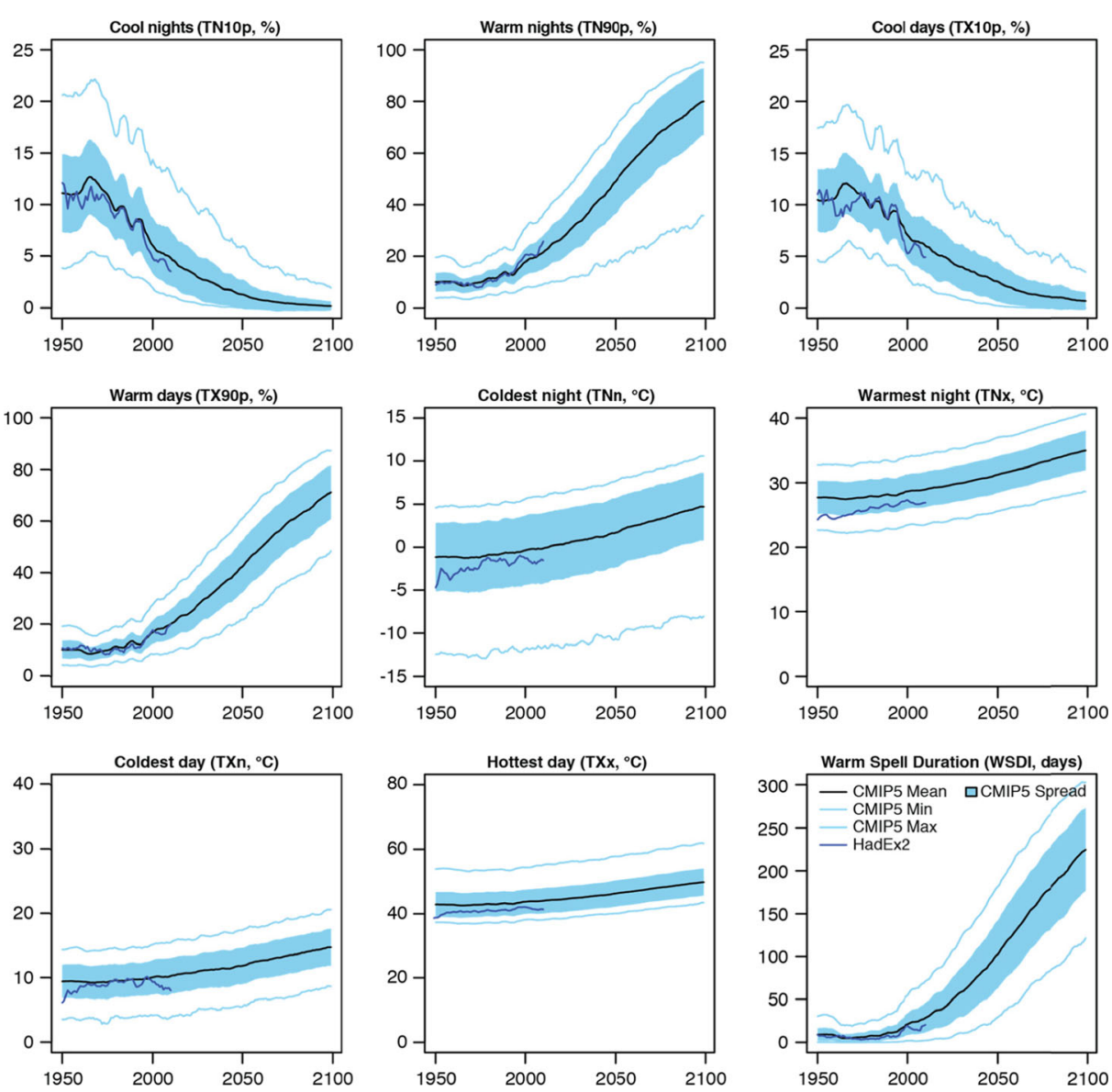

Fig. 4 Time evolution of temperature indices recommended by the ETCCDI calculated for the MENA from CMIP5 model results according to the RCP8.5 scenario, and from HadEX2 observations (dark blue lines)

The numbers of cool nights (TN10p) and cool days (TX10p) are the fractions of time when the daily minimum and maximum temperature, TN and TX, respectively, are below the 10th percentile (in \%). The numbers of warm nights (TN90p) and warms days (TX90p) are the fractions of time when TN and TX exceed the 90th percentile (in \%). TNn and TNx indicate the coldest and warmest nights, i.e., the monthly minimum and maximum values of daily minimum temperatures, respectively. TXn and TXx represent the coldest and hottest days, i.e., the monthly minimum and maximum values of the daily maximum temperature, respectively. The warm spell duration index (WSDI) is the annual count when at least six consecutive days of maximum temperature exceed the 90th percentile.

Sillmann et al. (2013a) showed that the CMIP5 model ensemble realistically represents climate extremes as well as trend patterns in comparison to the HadEX2 observational data. This is confirmed for temperature indices derived for the MENA in Table 1 and Figs. 4 and 5. Figure 4 shows that discrepancies between CMIP5 and HadEX2 indices are relatively largest in the early part of the record, e.g., for cool nights and days, the coldest and warmest night, the coldest and hottest day, while especially for the most recent decades - since about 1980 - the agreement is good; see the second and third columns of Table 1. In particular the agreement 

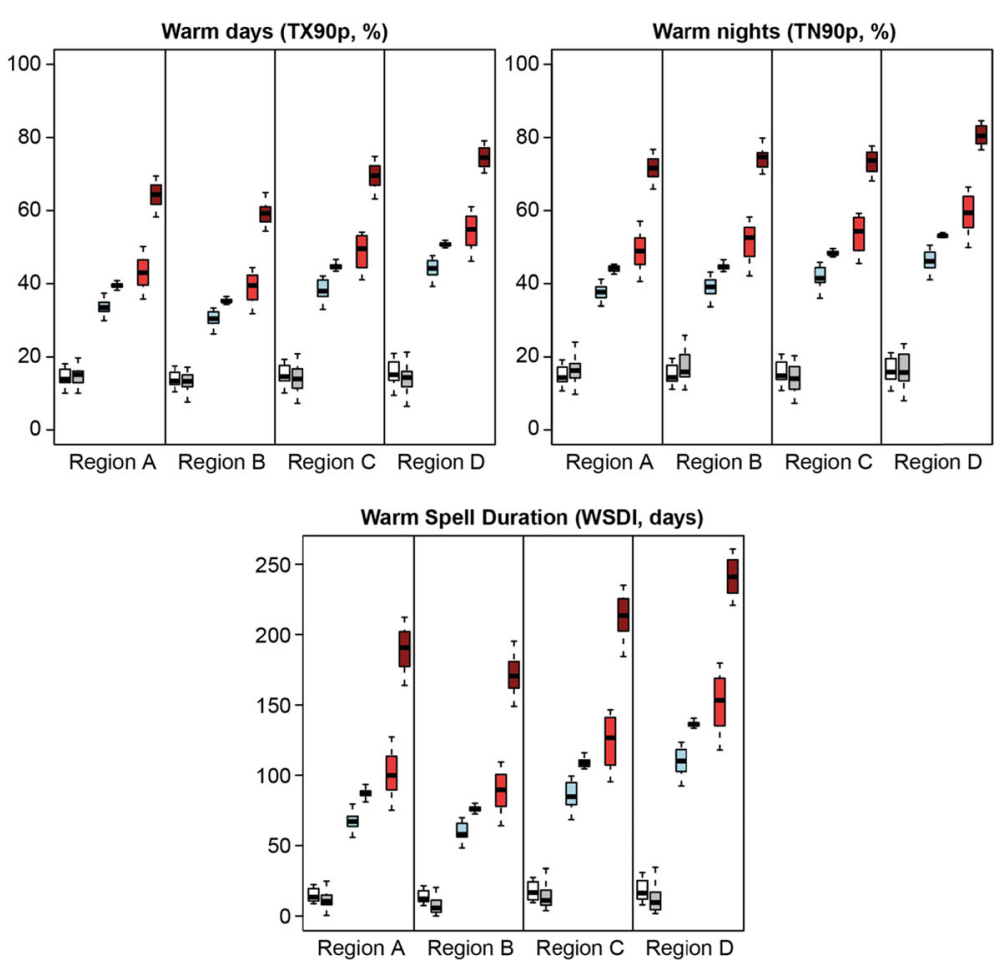

Fig. 5 Box-whisker plots for the temperature indices TX90p (warm days), TN90p (warm nights) and WSDI for the reference period 1986-2005 by CMIP5 (white) and HadEX (gray), the mid-century period 2046-2065 for RCP4.5 (light blue) and RCP8.5 (light red) and the end-century period 2081-2100 for RCP4.5 (dark blue) and RCP8.5 (dark red). The boxes include the median values, and the vertical dashed lines (whiskers) indicate the variability outside the lower and upper quartiles. For the regional averages, a land mask according to the availability of the HadEX2 indices was applied, except for region B where the overlap with model grid cells is only $10 \%$

between CMIP5 and HadEX2 data for warm days and nights (TX90p and TN90p) is very good (Fig. 5), being important indices for hot weather extremes and their impact on human health (Lubczyńska et al. 2015). Figure 5 also shows that the differences between the subregions are small for the reference period, while the projected increases of TX90p and TN90p in regions $\mathrm{C}$ and D are slightly larger than in regions A and B.

In general, the multi-model mean trends are close to the observations. Both, the observations and model calculations in Fig. 4 reveal that in the past decades the occurrence of heat extremes (TX90p and TN90p) has increased significantly while cool days and nights (TX10p and TN10p) have decreased. Sillmann et al. (2013b) mention for the future CMIP5 scenarios that Mediterranean extreme temperatures increase more strongly in summer than in winter, while in the rest of the world the reverse is more typical (see also Fang et al. 2008). This is corroborated by the results presented here, while we find that it actually applies to the entire MENA rather than only the Mediterranean.

The projected changes for both scenarios include steep decreases of the number of cool nights (TN10p) from about $7 \%$ in the reference period to about $1-2 \%$ by mid-century (Table 1 and Fig. 4). Additional decreases by the end of the century are small for RCP4.5 while TN10p approaches zero for RCP8.5. A similar tendency is projected for the number of cool days (TX10p), decreasing from about $8 \%$ to $2-3 \%$ by mid-century, and $1-2 \%$ by the end of 
the century. The numbers of warm nights and days are also projected to change strongly in the first half of the century. Warm nights (TN90p) increase from about $16 \%$ in the reference period to $41-54 \%$ by mid-century and warm days (TX90p) from $15 \%$ to $37-46 \%$, whereas both additionally increase by more than $20 \%$ towards the end of the century according to RCP8.5.

While the coldest nights (TNn) in the reference period are below the frost point, temperatures turn positive in the first half of the century, increasing further to more than $4{ }^{\circ} \mathrm{C}$ by the end of the century for RCP8.5. The coldest days (TXn) change from below $10{ }^{\circ} \mathrm{C}$ to about $12{ }^{\circ} \mathrm{C}$, and the warmest nights (TNx) from below to above $30{ }^{\circ} \mathrm{C}$ by mid-century, up to more than $34{ }^{\circ} \mathrm{C}$ by the end of the century for RCP8.5. In the reference period the hottest days (TXx) are about $43{ }^{\circ} \mathrm{C}$, increasing to about $46{ }^{\circ} \mathrm{C}$ by mid-century to more than $49{ }^{\circ} \mathrm{C}$ by end-century for RCP8.5. The WDSI is projected to increase steeply from about 16 days in the reference period to $83-118$ days by mid-century to more than 200 days by end of the century for RCP8.5.

\section{Conclusions}

To investigate climate change in the MENA we used the ensemble results of CMIP5 climate models, based on the RCP4.5 and RCP8.5 emission scenarios. We contrasted model results for the mid-century (2046-2065) and end-century (2081-2100) periods to the reference period 1986-2005, focusing on hot temperature conditions in summer. We performed comparisons with observations and robustness checks to evaluate the level of model agreement. While for precipitation projections the robustness is low, it is high for temperature. The comparison of modeled and observed temperature indices for the reference period indicates good agreement, especially for warm days and nights, being important for human health impacts.

The CMIP5 model projections suggest that climate warming in the MENA is much stronger in summer than in winter, while elsewhere the temperature increase is typically more pronounced in winter. This is important for a region where summers are already hot and dry. Exceptional summertime warming is associated with a thermal low, which is conceived as a widening of the Persian trough that extends from South Asia to the eastern Mediterranean, and is projected to expand westward and combine with the intensifying thermal low over the Sahara. The mechanism of desert warming amplification in summer involves increasing downward longwave radiation fluxes in the absence of evapotranspiration and a limited heat storage capacity of the dry soil.

To evaluate changing temperature extremes we adopted the ETCCDI indices recommended by the WMO. Observations and model calculations concur that heat extremes have become more frequent in the past decades while the occurrence of cool days and nights has decreased. For example, the number of warm days and nights has approximately doubled since the 1970s. Since the observed and modeled increasing heat extremes are absent in the CMIP5 control runs without radiative forcing, they are attributed to human-induced climate change. This trend is projected to continue in the first half of the 21 st century in both scenarios, and the number of warm days and nights will increase sharply. According to the RCP4.5 scenario the trend will moderate in the second half of the century, associated with the curbing of greenhouse gas emissions, while it continues in the RCP8.5 business-as-usual scenario. 
In the reference period the warmest nights are on average below $30^{\circ} \mathrm{C}$, while in both scenarios they will surpass $30^{\circ}$ by the middle of the century. In the RCP8.5 scenario they increase further to above $34^{\circ} \mathrm{C}$ by the end of the century. In the reference period the maximum daytime temperature during the hottest days is about $43{ }^{\circ} \mathrm{C}$, increasing to nearly $47^{\circ} \mathrm{C}$ by the middle of the century, and reaching nearly $50{ }^{\circ} \mathrm{C}$ by the end of the century in the RCP 8.5 scenario. In the reference period the average duration of warm spells is 16 days, with a projected increase to about 80-120 days by the middle of the century, while under the RCP8.5 scenario their number may exceed 200 by the end of the century. If these projected high temperatures become reality, part of the region may become inhabitable for some species, including humans, also suggested by Pal and Eltahir (2016).

We conclude that the MENA is a climate change hotspot that could turn into a scorching area in summer. There is general consent that heat extremes impact human health, contribute to the spreading of food- and water borne diseases, and that more intense heat waves increase premature mortality. In the past, climate assessments of social and economic impacts due to changing weather extremes, including consequences for human security and migration, have often focused on storms, floods, droughts and sea level rise. It is increasingly recognized that hot weather extremes cause a loss of work capacity and aggravate societal stresses, especially for disadvantaged people and vulnerable populations (IPCC 2014). We anticipate that climate change and increasing hot weather extremes in the MENA, a region subject to economic recession, political turbulence and upheaval, may exacerbate humanitarian hardship and contribute to migration.

Open Access This article is distributed under the terms of the Creative Commons Attribution 4.0 International License (http://creativecommons.org/licenses/by/4.0/), which permits unrestricted use, distribution, and reproduction in any medium, provided you give appropriate credit to the original author(s) and the source, provide a link to the Creative Commons license, and indicate if changes were made.

\section{References}

Almazroui M (2013) Simulation of present and future climate of Saudi Arabia using a regional climate model (PRECIS). Int J Climatol 33:2247-2259

Almazroui M (2015) RegCM4 in climate simulation over CORDEX-MENA/Arab domain: selection of suitable domain, convection and land-surface schemes. Int J Climatol. doi:10.1002/joc.4340

Almazroui M, Islam MN, Jones PD, Athar H, Rahman MA (2012) Recent climate change in the Arabian Peninsula: seasonal rainfall and temperature climatology of Saudi Arabia for 1979-2009. Atmos Res 111: 29-45

Alpert P, Osetinsky I, Ziv B, Shafir H (2004) A new seasons definition based on classified daily synoptic systems: an example for the Eastern Mediterranean. Int J Climatol 24:1013-1021

AlSarmi S, Washington R (2011) Recent observed climate change over the Arabian Peninsula. J Geophys Res 116:D11109. doi:10.1029/2010JD015459

Barnett J, Adger WN (2007) Climate change, human security and violent conflict. Political Geogr 26: 639-655

Basha G, Ouarda TBMJ, Marpu PR (2015) Long-term projections of temperature, precipitation and soil moisture using non-stationary oscillation processes over the UAE region. Int J Climatol. doi:10.1002/joc.4310

Basu R, Samet JM (2002) Relation between elevated ambient temperature and mortality: A review of the epidemiologic evidence. Epidemiol Rev 24(2):190-202

Bengtsson L, Hodges KI, Roeckner E (2006) Storm tracks and climate change. J Clim 19:3518-3543

Bitan A, Saaroni H (1992) The horizontal and vertical extension of the Persian Gulf pressure trough. Int J Climatol 12:733-747

Donat MG et al. (2013) Updated analyses of temperature and precipitation extreme indices since the beginning of the twentieth century: the HadEX2 dataset. J Geophys Res 118:2098-2118 
Donat MG et al. (2014) Changes in extreme temperature and precipitation in the Arab region: long-term trends and variability related to ENSO and NAO. Int J Climatol 34:581-592

Dunne JP, Stouffer RJ, John JG (2013) Reductions in labour capacity from heat stress under climate warming. Nature Clim Change 3:563-566

Efthymiadis D, Goodess CM, Jones PD (2011) Trends in Mediterranean gridded temperature extremes and largescale circulation influences. Nat Hazards Earth Syst Sci 11:2199-2214

Evan AT, Flamant C, Lavaysse C, Kocha C, Saci A (2015) Water vapor-forced greenhouse warming over the Sahara Desert and the recent recovery from the Sahelian drought. J Clim 28:108-123

Fang X, Wang A, S-k F, Lin W, Liu J (2008) Changes of reanalysis-derived Northern Hemisphere summer warm extreme indices during 1948-2006 and links with climate variability. Glob Plan Change 63:67-78

Gillett NP, Fyfe JC, Parker DE (2013) Attribution of observed sea level pressure trends to greenhouse gas, aerosol, and ozone changes. Geophys Res Lett 40:2302-2306

Giorgi G, Lionello P (2008) Climate change projections for the Mediterranean region. Glob Planet Chang 63:90-104

Giorgi F, Jones C, Asrar GR (2009) Addressing climate information needs at the regional level: the CORDEX framework. WMO Bulletin 58 (3), World Meteorological Organization, Geneva

Gosling SN, Lowe JA, McGregor GR, Pelling M, Malamud BD (2009) Associations between elevated atmospheric temperature and human mortality: A critical review of the literature. Clim Chang 92(3-4): 299-341

Hirschi M, Seneviratne S, Alexandrov V, Boberg F, Boroneant C, Christensen O, Formayer H, Orlowsky B, Stepanek P (2011) Observational evidence for soil-moisture impact on hot extremes in Southeastern Europe. Nature Geosci 4:17-21

Hoerling M, Eischeid J, Perlwitz J, Quan X, Zhang T, Pegion P (2012) On the increased frequency of Mediterranean drought. J Clim 25:2146-2161

IPCC (2013) Climate change 2013: The Physical Science Basis. Contribution of Working Group I to the Fifth Assessment Report of the Intergovernmental Panel on Climate Change, Stocker TF et al. (eds), Cambridge University Press, Cambridge, United Kingdom and New York, NY, USA, 1535 pp

IPCC (2014) Climate change 2014: impacts, adaptation, and vulnerability. part b: regional aspects. contribution of working group II to the fifth assessment report of the intergovernmental panel on climate change, Barros VR et al. (eds), Cambridge University Press, Cambridge, United Kingdom and New York, NY, USA, 688 pp

Klein Tank AMG, Zwiers FW, Zhang X (2009) Guidelines on analysis of extremes in a changing climate in support of informed decisions for adaptation, climate data and monitoring WCDMP-No 72, WMO-TD No 1500 , p 56

Knutti R, Sedlacek J (2012) Robustness and uncertainties in the new CMIP5 climate model projections. Nature Clim. Change 3:369-373

Koster RD, Schubert SD, Suarez MJ (2009) Analyzing the concurrence of meteorological droughts and warm periods, with implications for the determination of evaporative regime. J Clim 22:3331-3341

Kottek M, Grieser J, Beck C, Rudolf B, Rubel F (2006) World map of the Köppen-Geiger climate classification updated. Meteorol Z 15:259-263

Kovats RS, Hajat S (2008) Heat stress and public health: A critical review. Annu Rev Public Health 29:41-55

Kuglitsch FG, Toreti A, Xoplaki E, Della-Marta PM, Zerefos CS, Türkeș M, Luterbacher J (2010) Heat wave changes in the Eastern Mediterranean since 1960. Geophys Res Lett 37:L04802. doi: 10.1029/2009GL041841

Lelieveld J, Hadjinicolaou P, Kostopoulou E, Chenoweth J, El Maayar M, Giannakopoulos C, Hannides C, Lange MA, Tanarhte M, Tyrlis E, Xoplaki E (2012) Climate change and impacts in the Eastern Mediterranean and the Middle East. Clim Chang 114:667-687

Lelieveld J, Hadjinicolaou P, Kostopoulou E, Giannakopoulos C, Tanarhte M, Tyrlis E (2014) Model projected heat extremes and air pollution in the Eastern Mediterranean and Middle East in the twenty-first century. Reg Env Change 14:1937-1949

Lubczyńska MJ, Christophi CA, Lelieveld J (2015) Heat-related cardiovascular mortality risk in Cyprus: a case-crossover study using a distributed lag non-linear model. Environ Health 14:39. doi:10.1186/s12940-015-0025-8

Marofi S, Sohrabi MM, Mohammadi K, Sabziparvar AA, Abyaneh HZ (2010) Investigation of meteorological extreme events over coastal regions of Iran. Theor Appl Climatol 103(3-4):401-412

McMichael AJ, Woodruff RE, Hales S (2006) Climate change and human health: present and future risks. Lancet 367(9513):859-869

Mitchell TD, Jones PDJ (2005) An improved method of constructing a database of monthly climate observations and associated high-resolution grids. Int J Climatol 25:693-712 
Norrant-Romand C, Douguedroit A (2014) Significant rainfall decreases and variations of the atmospheric circulation in the Mediterranean (1950-2000). Reg Environ Chang 14:1725-1741

Önol B, Semazzi FHM (2009) Regionalization of climate change simulations over the Eastern Mediterranean. J Clim 22:1944-1961

Önol B, Bozkurt D, Turuncoglu UU, Sen OL, Dalfes HN (2014) Evaluation of the twenty-first century RCM simulations driven by multiple GCMs over the Eastern Mediterranean-Black Sea region. Clim Dyn 42: 1949-1965

Ozturk T, Ceber ZP, Türkeș M, Kurnaz ML (2015) Projections of climate change in the Mediterranean Basin by using downscaled global climate model outputs. Int J Climatol. doi:10.1002/joc.4285

Pal JS, Eltahir EAB (2016) Future temperature in Southwest Asia projected to exceed a threshold for human adaptability. Nature Clim Change 6:197-200

Peterson TC, Heim RR, Hirsch R, et al. (2013) Monitoring and understanding changes in heat waves, cold waves, floods and droughts in the United States: State of knowledge. Bull Amer Meteorol Soc 94:821-834

Piguet E, Pécoud A, de Guchteneire P (2010) Migration and climate change: an overview. centre on migration, policy and society, report 79, University of Oxford

Proestos Y, Christophides G, Ergüler K, Tanarhte M, Waldock J, Lelieveld J (2015) Climate model projections of vector-borne disease transmission by the Asian Tiger Mosquito (Aedes albopictus). Phil Trans R Soc B 370: 20130554. doi:10.1098/rstb.2013.0554

Rodwell MJ, Hoskins BJ (1996) Monsoons and the dynamics of deserts. Q J R Meteorol Soc 122:1385-1404

Sanchez E, Gallardo C, Gaertner MA, Arribas A, Castro M (2004) Future climate extreme events in the Mediterranean simulated by a regional climate model: a first approach. Glob Planet Change 44:163-180

Seidel DS, Fu Q, Randel WJ, Reichler TJ (2008) Widening of the tropical belt in a changing climate. Nature Geosci 1:21-24

Seneviratne SI, Corti T, Davin EL, Hirschi M, Jaeger EB, Lehner I, Orlowsky B, Teuling AJ (2010) Investigating soil moisture-climate interactions in a changing climate: A review. Earth Sci Rev 99:125-161

Seneviratne SI, Donat MG, Pitman AJ, Knutti R, Wilby RL (2016) Allowable $\mathrm{CO}_{2}$ emissions based on regional and impact-related climate targets. Nature 529:477-483

Sillmann J, Kharin VV, Zhang X, Zwiers FW, Bronaugh D (2013a) Climate extremes indices in the CMIP5 multimodel ensemble: part 1. Model evaluation in the present climate. J Geophys Res 118:1716-1733

Sillmann J, Kharin VV, Zhang X, Zwiers FW, Bronaugh D (2013b) Climate extremes indices in the CMIP5 multimodel ensemble: part 2. Future climate projections. J Geophys Res 118:2473-2493

Simolo C, Brunetti M, Maugeri M, Nanni T (2014) Increasingly warm summers in the Euro-Mediterranean zone: mean temperatures and extremes. Reg Environ Chang 14:1825-1832

Tanarhte M, Hadjinicolaou P, Lelieveld J (2012) Intercomparison of temperature and precipitation datasets based on observations in the Mediterranean and the Middle East. J Geophys Res 117:D12102. doi:10.1029/2011JD017293

Tanarhte M, Hadjinicolaou P, Lelieveld J (2015) Heat wave characteristics in the Eastern Mediterranean and Middle East using extreme value theory. Clim Res 63:99-113

Taylor KE, Stouffer RJ, Meehl GA (2012) A Summary of the CMIP5 experiment design. Bull Am Meteorol Soc 93:485-498

Tyrlis E, Lelieveld J, Steil B (2013) The summer circulation over the Eastern Mediterranean and the Middle East: influence of the south Asian monsoon. Clim Dyn 40:1103-1123

Tyrlis E, Skerlak B, Sprenger M, Wernli H, Zittis G, Lelieveld J (2014) On the linkage between the Asian summer monsoon and tropopause fold activity over the Eastern Mediterranean and the Middle East. J Geophys Res 119:3202-3221

Vizy EK, Cook KH, Cretat J, Neupane N (2013) Projections of a wetter Sahel in the twenty-first century from global and regional models. J Clim 26:4665-4687

Weigel A, Liniger M, Appenzeller C (2007) The discrete Brier and ranked probability skill scores. Mon Weather Rev 135:11-124

Willmott C, Matsuura K (1995) Smart interpolation of annually averaged air temperature in the United States. J Appl Meteorol 34:2577-2586

World Meteorological Organization (2009) Guidelines on Analysis of extremes in a changing climate in support of informed decisions for adaptation. Climate Data and Monitoring WCDMP-No. 72, WMO, Geneva

Xoplaki E, Gonzalez-Rouco JF, Luterbacher J, Wanner H (2004) Wet season Mediterranean precipitation variability: influence of large-scale dynamics and trends. Clim Dyn 23:63-78

Yin JH (2005) A consistent poleward shift of the storm tracks in simulations of 21 st century climate. Geophys Res Lett 32:L18701. doi:10.1029/2005GL023684

Zarenistanak M, Dhorde AG, Kripalani RH (2014) Temperature analysis over southwest Iran: trends and projections. Theor Appl Climatol 116:103-117 
Zander KK, Botzen WJW, Oppermann E, Kjellstrom T, Garnett ST (2015) Heat stress causes substantial labour productivity loss in Austratlia. Nature Clim Change 5:647-651

Zhang X et al. (2005) Trends in Middle East climate extreme indices from 1950 to 2003. J Geophys Res 110 : D22104. doi:10.1029/2005JD006181

Zhang X, Alexander L, Hegerl GC, Jones P, Tank AK, Peterson TC, Trewin B, Zwiers FW (2011) Indices for monitoring changes in extremes based on daily temperature and precipitation data. Clim Chang 2:851-870

Zittis G, Hadjinicolaou P, Lelieveld J (2014a) CL-WRF senisitivity to physics parameterizations over the Middle East and North Africa. Am J Clim Change 3:490-511

Zittis G, Hadjinicolaou P, Lelieveld J (2014b) Role of soil moisture in the amplification of climate warming in the Eastern Mediterranean and the Middle East. Clim Res 59:27-37

Zittis G, Hadjinicolaou P, Fnais M, Lelieveld J (2015) Projected changes of heat wave characteristics in the Eastern Mediterranean and the Middle East. Reg Environ Chang. doi:10.1007/s10113-014-0753-2

Ziv B, Saaroni H, Alpert P (2004) The factors governing the summer regime of the Eastern Mediterranean. Int J Climatol 24:1859-1871

Ziv B, Saaroni H, Pargament R, Harpaz T, Alpert P (2014) Trends in rainfall regime over Israel, 1975-2010, and their relationship to large-scale variability. Reg Environ Chang 14:1751-1764 